"big science"' appears to have won a battle with a 15 per cent increased allocation to major projects. Two are singled out for partial funding in 1984: HERA, a large electron-proton collider for the DESY laboratory in Hamburg, and BER II, a research reactor for Berlin. Two others are put on hold: SIS, a heavy ion synchrotron for GSI Darmstadt and a spallation neutron source for Jülich. Robert Walgate

\section{UK biotechnology \\ Celltech signs up}

Celltech Ltd, the British biotechnology company, is further strengthening its commercial links with Japan. Celltech has granted licences to the Sankyo Company of Tokyo which give it world-wide marketing rights for two therapeutic products that will be developed at Celltech's laboratories in Britain. Celltech will receive licensing fees, development costs and royalties.

The two products are human tissue plasminogen activator and calcitonin, a hormone involved in calcium regulation. Celltech has already cloned genes for both molecules in bacteria and hopes to have the products on the market within four years. Sankyo will be responsible for scaling up production on commercial levels. The two companies will also collaborate in research on katacalcin, a recently-discovered hormone with properties similar to calcitonin.

Tissue plasminogen activator (t-PA) is a thrombolytic agent that has potential to replace urokinase and streptokinase, both of which have the disadvantage that their action is relatively unspecific and that they may stimulate a troublesome immune reaction. The Japanese market for thrombolytics is valued at $£ 100$ million a year, although such products are much less widely used in the United States. But a cost effective replacement with the advantages of t-PA might change that. Celltech is not alone in the race: at least two other companies, Biogen in Switzerland (collaborating with Fujisawa in Japan) and Genentech Inc. in the United States are also working on human t-PA.

Calcitonin is at present used in treating Paget's disease and hypercalcaemia. It may also prove to be useful for osteoporosis, which is a disease of considerable economic importance, being the cause of many bone fractures in older women.

In July, the state-backed British Technology Group's stake in Celltech was reduced from 44 to 28 per cent, and Celltech has successfully attracted specialist investors. The latest announcement will be seen as further evidence of Celltech's determination to reap the financial rewards of its expertise. Celltech coyly let slip at the announcement of the agreement that it has turned down several offers for similar deals with "other international pharmaceutical companies".

Tim Beardsley

\title{
Artificial sweeteners
}

\section{Sour welcome for aspartame}

THE atmosphere was far from sweet at last week's British launch of G. D. Searle and Company's new artificial sweetener, aspartame. Professor Richard J. Wurtman of the Massachusetts Institute of Technology has raised questions about the effects on brain chemistry of high doses of aspartame, and the Searle representatives at the launch were prepared for a fight.

Aspartame (a dipeptide of aspartic acid and the methyl ester of phenylalanine) is one of three new high intensity sweeteners approved for unrestricted use in Britain on 6 September, and Searle expects to capture a large part of the UK market for lowcalorie sweeteners. Aspartame is already on the market in several countries (including the United States, Canada and France) and Searle is plainly delighted with its reception. The product is claimed to taste like sugar, which should give it a substantial advantage over saccharin. Searle's patent on the use of aspartame expires in 1987. Small wonder, then, that Searle disputes the significance of Wurtman's results.

Wurtman's data (New England Journal of Medicine 18 August) show that high doses of aspartame given to rats produce a rise in brain levels of aromatic amino acids (including phenylalanine) and that the effect is potentiated by glucose. Aspartame blocks the rise in serotonin levels that normally follows glucose ingestion. Wurtman suggests that aspartame, while not toxic in the usual sense, may affect mechanisms controlling carbohydrate and protein intake and raise phenylalanine levels dangerously in susceptible individuals. Although other foods may contribute much larger amounts of phenylalanine (Phe) to the diet, they contain other amino acids that compete for access to the brain and so limit brain levels of Phe.

Because of impaired Phe metabolism, people suffering from phenylketonuria will certainly have to be wary of aspartame. In order to avoid brain damage caused by an increase of Phe to toxic levels, severe cases must limit their intake to around $200 \mathrm{mg}$ per day. A circular produced by Sir Henry Yellowlees, Chief Medical Officer at the Department of Health, points out that soft drinks sweetened with aspartame may contain up to $400 \mathrm{mg}$ of Phe per litre.

Searle has voluntarily announced that it will include a warning to phenylketonurics on its own aspartame product and will encourage other manufacturers to do likewise. As phenylketonurics all know that they have the disease and have anyway to follow an extremely restricted diet, it will be possible for them to avoid aspartame.

The real controversy is whether other groups could be affected. Wurtman is not concerned about low levels of aspartame he uses the product himself - but says that the behavioural tests necessary to deter- mine the effects of high doses have not been carried out. A child drinking soft drinks in large quantities will, he says, approach levels of phenylalanine equivalent to those in his experimental subjects. Wurtman says these levels are well within the range that might produce behavioural effects. Other authorities are more sceptical, saying that the changes Wurtman has observed are within the range of normal variation. But if he is right, individuals heterozygous for the phenylketonuria gene, who have a slightly impaired Phe metabolism, might be more at risk than others.

Wurtman's conclusions have been rejected by the US Food and Drug Administration, but Wurtman maintains that his points have not been answered. The data have not yet been formally considered by the UK Department of Health's Committee on Toxicity, but Labour Member of Parliament Jack Ashley has asked for an emergency meeting to discuss aspartame. The committee will otherwise next meet in October. Searle says it is fully confident that the authorities will have no reason to reconsider their decision. It is also pointed out that no ill-effects have been encountered with the product in the many countries where it is in use. Tim Beardsley

\section{Mediterranean treaty}

SOME 85 per cent of all sources of pollution in the Mediterranean are now under control, at least on paper. Last month the $\mathbf{1 9 8 0}$ Athens treaty on land-based sources of pollution, inspired by the United Nations Environment Programme (UNEP), came into force with its ratification by six of the original sixteen signatories.

The six ratifiers are Algeria, Tunisia, Egypt, Turkey, Monaco and France, which, through the Rhône river, is one of the major industrial and agricultural polluters of the Mediterranean. The remaining ten signatories are near ratification, says UNEP. Full implementation of the treaty would cost some $£ 7,000-10,000$ million, UNEP estimates, and it expects that money to be spent in the next 10-15 years.

According to Dr Mustafa Tolba, executive director of UNEP, pollution monitoring shows that because of untreated sewage, 20-25 per cent of Mediterranean bathing beaches are now unsafe for bathing, and that only 4 per cent of shellfish-growing areas produce shellfish "safe for direct consumption". Some coastal waters are also showing signs of eutrophication, Tolba says. The resulting loss of revenues from tourism and fishing are difficult to estimate, but it seems that the threat of such losses is now the chief incentive to ratify the Athens treaty.

Robert Walgate 